\title{
Science Instruction through the Game and Physical Activities Course: An Interdisciplinary Teaching Practice
}

\author{
Celal Boyraz", Gökhan Serin
}

Faculty of Education, Anadolu University, Turkey

Copyright $\mathrm{C} 2017$ by authors, all rights reserved. Authors agree that this article remains permanently open access under the terms of the Creative Commons Attribution License 4.0 International License

\begin{abstract}
The purpose of this study was to examine the effect of science instruction given through the game and physical activities course in accordance with interdisciplinary teaching approaches on students' science achievement and retention. The participants were 82 third grade students from a public elementary school. Three classes were chosen as experimental groups and one class was chosen as a control group in the school. The instruction period lasted for five weeks in all groups. The data were collected by an achievement test and an education portal achievement (EPA) test. The pretest-posttest control group design was used in the study. Data obtained from the tests were analyzed through one-way analysis of variance and post-hoc analyses. The findings indicated that some of the experimental groups were more successful than the control group with large effect sizes. The results suggested that the game and physical activities course incorporating interdisciplinary teaching approaches could be used in increasing students' science achievement and retention of science knowledge.
\end{abstract}

Keywords Interdisciplinary Teaching, Science Education, Game and Physical Activities, Elementary School, Achievement

\section{Introduction}

Physical education is a critical part of learning. Movement experiences have many benefits for children. They exercise the whole body, including the mind and not just the muscles; the exercise can help the children to develop a lifetime desire for health, fitness and success in all areas of academic learning [1]. Beyond that, for children, movement is certainly joyous. Moreover, studies of how young children learn have proven that they especially acquire knowledge experientially - through play experimentation, exploration, and discovery. Today's emerging research on the brain shows this to be true that there is indeed a link between moving and learning [2]. Movement allows children to be more confident of their own skills, while contributing to their success because of their self-confidence and self-respecting experience. In this context, physical education in primary school level is a very important course for the cognitive development of children, because children can learn other disciplines such as science, mathematics, social science, language, art and music through physical education.

It is possible to have some scientific experience through physical education, which is the subject of this paper. It is necessary to implement interdisciplinary teaching in order to benefit from these possibilities. Interdisciplinary teaching has been applied to physical education in subject areas such as science, reading, dance and art [3-4]. The value of interdisciplinary teaching in physical education is that it enables children to use their strengths and existing knowledge, which may encourage children who are not as easily engaged in physical activities to participate more actively [5]. In this regard, it is stated that there is a need for an interdisciplinary teaching environment in which students are equipped with theoretical knowledge through extracurricular activities, and which can be implemented in a class considering individual differences, or outside the class [3]. This is because interdisciplinary teaching is an approach that tells us to focus on the problem by bringing together our knowledge and skills in the solution of problems encountered in daily life [6]. In other words, the problems that is encountered is tried to be solved by using together all pieces of knowledge gained without questioning how much mathematics, physics or geography is needed to solve such problems. As teaching students multifaceted thinking skills, interdisciplinary teaching provides them more real-life like learning environments [7]. Therefore, it is thought that interdisciplinary teaching approach can be beneficial for experiential science education that has equivalence in real life. In the literature, it is suggested that there is a need for interdisciplinary learning environments that enables practicing learned science concepts in the class or outside the school [4-8-9-10-11]. Based on this suggestion, in this study, an interdisciplinary learning environment was designed from the perspective of the game and physical activities course that has an important place for elementary school students in 
a way that is fun, experiential, active and that can associate the concepts of the science course to daily life, and the effects of this environment was examined.

\section{Game and Physical Activities (GPA) Course and Science Education}

The GPA course is conducted in elementary school since 2012, in Turkey. This course is game based physical education. The GPA course can be argued to be one of the most natural ways for putting science principles and concepts into practice. This is because the GPA course naturally includes cases of desire to play games, enjoying games, and being physically active, which are observed intensely in elementary school children. Besides, most of elementary school children's time passes with games and moving around.

From the perspective of children's development areas, games are of great important as well. Games are positively related to children's cognitive, psychomotor, social, affective and language development areas [12]. In addition, games create a valuable learning atmosphere for children. While playing games, their attention, interest, curiosity and desire are all automatically active, and their imagination and creativity develop. Games enable children to learn basic science concepts whereas giving them the opportunity to express their feelings and energy freely [13].

Even if the information is presented to students by establishing connections from students' daily life in a way that attracts their attention, it is not usually possible for children to experience those pieces of information. However, science subjects include many activities that are actually experienced in daily life. In the literature, there are studies in which science subjects such as force and motion, muscle and skeletal structure, the Newton laws, simple machines, and operation of body systems are taught by means of physical activities. In these studies, it is seen that the science teaching based on physical activities is usually done using the basic arguments of the physical education course [9-10-11-14-15-16-17]. In other words, science teaching was done through characteristics of physical skills such as in volleyball, football, or jumping. These studies were conducted mostly at middle school and high school levels. Besides, in this study, considering that science teaching merely based on physical activities would be far from fun at elementary school level, an interdisciplinary science teaching was designed by using games in the science course in accordance with the content of the GPA course. This aspect stands out as the difference of this study from others in the literature. In this way, it is thought that an active, participating, fun and real-life like science teaching could be presented to children of elementary school age as the period in which they need physical activity at most. Moreover, in the literature, there was no clear explanation on when to introduce science concepts while students engage with the GPA, i.e. before the GPA, during the GPA, or after the GPA. For this reason, in this study, we aimed to develop three treatments that take into account timing of introduction of science concepts while students conduct the GPA. In this regard, the research question addressed in the study was "What is the effect of three types of science instruction done with an interdisciplinary teaching approach based on the GPA course on students' academic achievement in science and retention of science knowledge?"

\section{Method}

\section{Research Design}

The study was designed based on the pretest-posttest quasi-experimental model with a control group. It was conducted within the scope of the unit "Let's Learn About Force" included in the elementary 3rd grade science course in the 2014-2015 school year.

\section{Population and Sample}

The population of the study is the third grade elementary students aged about nine years old in Şarhöyük education zone of the Tepebaşı District Directorate of National Education in Eskişehir province in Turkey. This education zone generally has students with medium and low academic achievement. There are eight elementary schools in this education zone. Four of these schools were not included in the population because they provided education in multi-grade classes, and the remaining 4 schools and 361 third grade students in 16 classes in these schools were determined as the accessible population. All third grades in four classes in one of these elementary schools selected through convenience sampling method constituted the sample of the study $(n=82)$ that was nearly $23 \%$ of the accessible population. The distribution of the students based on groups and gender is presented in Table 1. In the table, the groups in which the science concepts were taught at the beginning of, during, or at the end of the activities were listed as "Experiment 1", "Experiment 2", and "Experiment 3", respectively.

Table 1. Distribution of participants based on groups and gender

\begin{tabular}{|c|c|c|c|c|}
\hline Groups & Male & Female & Frequency $(f)$ & Percentage (\%) \\
\hline Control & 7 & 11 & 18 & 22.0 \\
\hline Experiment 1 & 8 & 14 & 22 & 26.8 \\
\hline Experiment 2 & 7 & 14 & 21 & 25.6 \\
\hline Experiment 3 & 7 & 14 & 21 & 25.6 \\
\hline Total & 29 & 53 & 82 & 100.0 \\
\hline
\end{tabular}

The socioeconomic level of the families in this population was generally low. The environment of the students can be described as the suburban area. Considering the variables of the study, and the school administrators' and teachers' statements, there was no sign of a difference revealed 
between the students in the sample and those in the rest of the population. Therefore, it can be argued that the findings obtained with the sample can be generalizable to the population. On the other hand, the practices in the experimental groups were implemented in the school garden with a basketball hoop and lines, and different game materials. The generalizability of the results to the population can only be valid if these physical conditions are met.

\section{Pilot Study}

A pilot study was conducted before the actual implementation to see the functioning of the activities. In the pilot study, which aimed to teach the unit "Let's Learn about Force" of the third grade science course based on the GPA course, eight game-based physical activity plans were firstly prepared, and applied with 36 students. It was observed that the emphasis of competition is important in preparing this kind of activities, and game rules should be easily comprehended by students. Another important feedback received from the pilot study was that students do not want to continue the lesson in the class after playing outside to talk about science concepts. The new activities and lesson plans used in the actual implementation were designed in light of these pieces of feedback.

\section{Data Collection Tools}

\section{Achievement Test}

A multiple-choice pretest consisting of 16 items and a posttest with the same number of items parallel to this pretest were developed to be used in the pilot study with regard to the outcomes of the unit "Let's Learn about Force" in the third grade science course. These tests were employed to see whether the activities applied in the pilot study contributed to the students' learning. The questions were enriched with examples from daily life. A new 16-item achievement test was formed based on the feedback received from the students related to the 32 items in total used as pretest and posttest in the pilot study in terms of question root, intelligibility of options, and easiness/difficulty. This test was administered to 152 elementary 3 rd graders for validity and reliability analyses. ITEMAN, an item and test analysis program was used to analyse each item. As a result of the analyses, the Cronbach's Alpha reliability coefficient was found as 0,69. The item difficulty mean was 0,51 and the item discrimination mean was 0,53 . Following the analyses, it was decided to revise some of the items. One item was discarded because of its low item difficulty level. The alternatives of one easy item were revised so that its difficulty level would be increased. The stem and alternatives of three difficult questions were revised in order to make their difficulty level medium. Consequently, the multiple-choice achievement test consisting of 15 items was finalised. The test was examined by a physics education expert in terms of scientific accuracy by means of the table of specifications in Table 2 , and its content validity was ensured. It was used as the pretest, posttest, and retention test, which was administered six months after the posttest, without any change.

Table 2. Table of specifications for the achievement test

\begin{tabular}{|c|c|c|c|c|c|c|c|c|}
\hline \multirow[b]{2}{*}{ Topic } & \multicolumn{6}{|c|}{ Outcome Level } & \multicolumn{2}{|c|}{ Question } \\
\hline & Knowledge & Comprehension & Application & Analysis & Synthesis & Evaluation & Percentage $(\%)$ & Total(f) \\
\hline $\begin{array}{l}\text { Acceleration, } \\
\text { Deceleration, } \\
\text { Turning, }\end{array}$ & & & & & & & & \\
\hline $\begin{array}{l}\text { Swinging and } \\
\text { Deflection }\end{array}$ & & 1 & & & & & 26.6 & 4 \\
\hline $\begin{array}{l}\text { Push and Pull } \\
\text { Forces }\end{array}$ & & 2 & & & & & 26.6 & 4 \\
\hline $\begin{array}{l}\text { Force, Push and } \\
\text { Pull Forces }\end{array}$ & & 3 & & & & & 26.6 & 4 \\
\hline $\begin{array}{c}\text { Moving and } \\
\text { stopping } \\
\text { objects }\end{array}$ & & 4 & & & & & 20 & 3 \\
\hline
\end{tabular}


The numbers shown in Table 2 under the title outcome level are the numbers assigned to the outcomes (see Table 6). The Cronbach's Alpha value, and item difficulty and item discrimination mean values for the pretest, posttest and retention test are presented in Table 3. Accordingly, it can be argued that the achievement tests were reliable, and the items were discriminatory [18]. It can be stated that the test was difficult in the pretest administration, whereas it was easy in the posttest and retention test administrations. This is expected as a result of instruction. A sample question from the achievement test is given in Table 4 .

Table 3. Item and reliability values for the achievement pretest, posttest and retention test

\begin{tabular}{|c|c|c|c|}
\hline $\begin{array}{c}\text { Achievement } \\
\text { Test }\end{array}$ & $\begin{array}{c}\text { Cronbach's } \\
\text { Alpha }\end{array}$ & $\begin{array}{c}\text { Item Difficulty } \\
\text { Mean }\end{array}$ & $\begin{array}{c}\text { Item } \\
\text { Discrimination } \\
\text { Mean }\end{array}$ \\
\hline Pretest &, 66 &, 53 &, 55 \\
\hline Posttest &, 62 &, 77 &, 53 \\
\hline Retention &, 63 &, 74 &, 62 \\
\hline
\end{tabular}

Table 4. Sample questions from the achievement and EPA tests

\begin{tabular}{|c|c|}
\hline Test & Sample question \\
\hline $\begin{array}{c}\text { Achievement } \\
\text { test }\end{array}$ & $\begin{array}{l}\text { If we let a supermarket car downhill, what kind of } \\
\text { motion does it have? } \\
\text { A. Motion with increasing speed } \\
\text { B. Motion with decreasing speed } \\
\text { C. Swinging motion }\end{array}$ \\
\hline EPA Test & $\begin{array}{l}\text { Which one of the following have a motion with } \\
\text { increasing speed? } \\
\text { A. A bus approaching the bus stop } \\
\text { B. A ship approaching the port } \\
\text { C. An airplane taking off }\end{array}$ \\
\hline
\end{tabular}

\section{Educational Portal Achievement Test (EPA test)}

In the control group, a web-based educational portal, which was free for all teachers, was frequently used for lecturing and various assessment practices. Since this portal included end-of-unit tests, a new test, called the EPA Test, including 15 multiple-choice items was prepared by the researchers by selecting questions from these tests, and its content validity was ensured through an examination in terms of scientific accuracy by means of the table of specifications presented in Table 2. The purpose of using this test was to see the level of achievement across the experimental groups in the end-of-unit tests appeared in the instructional materials of the control group. In this way, an alternative step was taken against a possible bias by the researchers in favour of the experimental groups in the process of developing the achievement test. It was decided to administer this test to all groups after the instruction and as a retention test six months later. The Cronbach's Alpha value, and item difficulty and item discrimination mean values for the EPA tests are presented in Table 5.
Table 5. Item and reliability values for the EPA tests

\begin{tabular}{|c|c|c|c|}
\hline EPA & $\begin{array}{c}\text { Cronbach's } \\
\text { Alpha }\end{array}$ & $\begin{array}{c}\text { Item Difficulty } \\
\text { Mean }\end{array}$ & $\begin{array}{c}\text { Item } \\
\text { Discrimination } \\
\text { Mean }\end{array}$ \\
\hline $\begin{array}{c}\text { Post-Instruct } \\
\text { ion }\end{array}$ &, 60 &, 68 &, 45 \\
\hline $\begin{array}{c}\text { Retention } \\
\text { Test }\end{array}$ &, 67 &, 79 &, 48 \\
\hline
\end{tabular}

Based on these values, it can be stated that the test was reliable, discriminatory and slightly easy [19]. The test was actually expected to be easy because it was administered right after the students finished the unit. A sample question from the EPA test is given in Table 4.

\section{Experimental Procedure}

The treatment developed in this study was to teach students science through an interdisciplinary approach with the help of the GPA course. Three strategies were generated to deliver the treatment in the experimental groups. The difference between the strategies was the timing of introduction of science concepts while students conduct GPAs. The classes 3-A, 3-C and 3-D were the experimental groups, while the class 3-B was the control group. Each class was taught by only one elementary school teacher who are responsible to teach many courses. The teachers voluntarily decided which group (experimental or control) they will be. Based on which strategy the experimental groups would be taught was determined by random selection. Accordingly, it was planned that the science concepts would be presented during the activities in 3-A, at the beginning of the activities in 3-C, and at the end of the activities in 3-D. The GPA-based experimental procedure and the control group instruction were implemented only in the science course hours that were three hours in a week. The experimental procedure lasted in five weeks. Before the treatments, students were given the achievement test as a pretest. After the treatments, students were administered the achievement test and the EPA test as posttest. Six months later those tests were administered as a retention test. Different teachers in each class would possibly affect or change the target treatments because of their personal or professional characteristics. In order to minimize this effect, before the implementation, the teachers of the experimental groups were told in detail how the lessons would be delivered on sample lesson plans. Any confusion that the teachers had was eliminated. On the other hand, the teacher of the control group was asked to deliver the lessons as usual. Moreover, all classes were observed by an observer through completing a checklist in order to see if the teachers followed their lesson plans or done different things apart from the lesson plans due to their characteristics. Thus, we were able to understand if the teacher characteristics interfered with the treatments. 


\section{Developing Interdisciplinary Lesson Plans}

When the third grade curricula of the science and GPA courses were examined, it was seen that the outcomes of the unit "Let's Learn about Force" in the science course, and those of the GPA course were compatible. These outcomes are presented in Table 6 .

In the literature, the interdisciplinary teaching approach does not have a single understanding. Particularly within the scope of integrated curriculum, the term 'interdisciplinary' is frequently used as a curriculum model [19-20-21]. In this study, it is thought that student outcomes related to force and motion can be taught to students through the GPA course based on Placek and O'sullivan's [22] idea of focusing on other disciplines from the perspective of physical education. Accordingly, the outcomes presented in Table 6 were included in 12 game-based physical activities.

The outcomes were integrated to the games from simple to complex. After this step, each plan was prepared separately for each experimental group. In other words, for a science lesson that would be delivered through a game, three lesson plans using different strategies in each experimental group were prepared. A total of 36 lesson plans were used in the procedure. The names of the games, their sources, science outcomes and implementation times are presented in Table 7.

Outcome 4, which is "Students discuss the dangers caused by moving objects in daily life", was included in all lesson plans. This is because of the possibility of students' encountering a dangerous situation due to the nature of the GPA course any time. As a matter of fact, there were some slightly dangerous situations in the implementation, and the teachers emphasized this outcome.

\section{Instructional Procedure}

The teacher in the control group (3-B) taught the class as what the science curriculum states. There was no researcher-made treatment in the control group. In this regard, the control group teacher started to present the topic with the course book. She then completed the instruction using the web-based education portal. During teaching, modules such as animations, puzzles, interactive activities, and experiment videos were used. Then, the students again did the interactive activities included in the education portal. Whereas the teacher mostly used the education portal for presenting the topic and evaluation questions, she assigned the students to answer the evaluation questions in the workbook at home.

Table 6. Student Outcomes of the science unit "Let's Learn about Force" and the GPA course

\begin{tabular}{|c|c|}
\hline Outcomes of the science unit "Let's Learn About Force" & Outcomes of the GPA Course \\
\hline $\begin{array}{c}\text { 1. Students observe moving entities and notice their motion } \\
\text { characteristics. }\end{array}$ & $\begin{array}{c}\text { 1. Students make movements with increased agile. } \\
\text { 2. Students discover that push and pull are forces. }\end{array}$ \\
\hline $\begin{array}{c}\text { 3. Students explain the concept of force by observing the effects of push } \\
\text { and pull forces on objects at rest and moving. } \\
\text { awareness of body surface area, and movement relationships. }\end{array}$ & $\begin{array}{c}\text { 3. Students make movements that require control over objects with } \\
\text { increased accuracy by using awareness of surface area, effort and } \\
\text { movement relationships. }\end{array}$ \\
\hline 4. Students discuss the dangers caused by moving objects in daily life. & $\begin{array}{c}\text { 5. Students explain the elements that pose a risk for themselves and their } \\
\text { peers in games and physical activities with reasons. }\end{array}$ \\
\hline
\end{tabular}

Table 7. Names of games, sources, outcomes and implementation dates

\begin{tabular}{|c|c|c|c|}
\hline Name of the game & Source & Science Outcomes & Implementation time \\
\hline 1.Stop & Traditional & 1 and 4 & Week 1 \\
\hline 2.Run Fast & Curriculum & 1 and 4 & Week 1 \\
\hline 3. Dodgeball & Traditional & 1 and 4 & Week 1 \\
\hline 4.Lamb and Wolf & Researchers & 1,2 and 4 & Week 2 \\
\hline 5.Lamb and Sheep & Researchers & 1,2 and 4 & Week 2 \\
\hline 6.Rabbit Race & Researchers (Adaptation) & 1,2 and 4 & Week 2 \\
\hline 7.Tug of War & Traditional & $1,2,3$ and 4 & Week 3 \\
\hline 8.Seven Towers & Traditional & $1,2,3$ and 4 & Week 3 \\
\hline 9.Scored a Goal! & Researchers & $1,2,3$ and 4 & Week 3 \\
\hline 10.Flying Saucer & Researchers (Adaptation) & $1,2,3$ and 4 & Week 4 \\
\hline $\begin{array}{l}\text { 12. Swinging Balloon } \\
\text { 13. Flying Saucer } \\
\text { 14. Turkish Baseball } \\
\text { 15. Swinging Balloon }\end{array}$ & $\begin{array}{c}\text { Researchers } \\
\text { Researchers (Adaptation) } \\
\text { Researchers (Adaptation) } \\
\text { Researchers }\end{array}$ & $\begin{array}{l}1,2,3 \text { and } 4 \\
1,2,3 \text { and } 4 \\
1,2,3 \text { and } 4 \\
1,2,3 \text { and } 4\end{array}$ & $\begin{array}{l}\text { Week } 4 \\
\text { Week } 5 \\
\text { Week } 5 \\
\text { Week } 5\end{array}$ \\
\hline
\end{tabular}


The 12 activities designed for the experimental groups were implemented as one activity for each of the 12 lessons in the first four weeks. At the end of the four weeks, the students were asked to name three of the game-based physical activities that they liked most, and these three activities were implemented again in the fifth week.

In the experimental group (3-C) in which concepts were taught at the beginning of the activities, the teacher firstly presented the science concepts to directly the students gathered in the school garden. She then divided the students into groups depending on the type of the activity. She asked the students who could detect the concept presented at the beginning within the game to inform her during the game. These steps took nearly five minutes. The game then started with the teacher having a referee role. After the game that lasted about 25 minutes, the teacher asked the students to gather around in a circular shape. The teacher, who was in the middle of the circle, asked the students the questions included in the lesson plan and wanted them to answer these questions. For instance, the students were asked the question "What moves a frisbee?", and were expected to give the answer "force". The duration for this question-answer step was set as 10 minutes, and afterwards, the lesson was completed.

In the experimental group (3-A) in which the concepts were taught during the activities, the game started after the game rules were told. During the game, the teacher paused the activity by means of a referee's whistle at the point when a concept was experienced, and the students were asked questions related to this concept in the lesson plan. The teacher taught the concept based on the students' answers and the event that came up during the game, and the game continued where it was left. After 30 minutes, the teacher informed the students that the game ended by using the whistle, and asked them to gather around him. In the last 10 minutes of the course, the teacher summarized the science concepts included in the game, and gave the students the opportunity to ask questions and give similar examples, and the lesson ended.

In the experimental group (3-D) in which the science concepts were taught at the end of the activities, the teacher launched the game after informing the students about the rules. The game continued for nearly 25 minutes without any interruption. In the meantime, the teacher acted as the referee of the game. After the game, the teacher blew the whistle and asked the students to gather around her, and did direct teaching related to the science concepts for five minutes. Afterwards, she asked the students questions included in the lesson plan such as whether a science concept could be spotted in the game. The question-answer part lasted about 10 minutes, and the lesson ended.

Implementations in both the control and experimental groups were lasted in five weeks. The basic difference between the teaching of the control group and the experimental groups was the teaching environment. This is because the experimental groups attended the lessons in the school garden, whereas the lessons of the control group were in the classroom environment. Besides, in the experimental groups, game-based physical activities and materials related to these were used in every lesson. This was not the case in the control group where instructional materials were mainly based on the web-based education portal and the course book.

\section{Data Analysis}

In the achievement test and the EPA test, each correct answer was given one point. The maximum score was 15 points, and the minimum was zero points in these tests. After the pretest, posttest and retention test scores of the experimental groups and the control group were obtained the mean scores of the groups and other descriptive statistics were calculated. To examine whether the data showed a normal distribution, Shapiro-Wilks normality test, skewness and kurtosis coefficients, histogram, and box plot were used. As a result, the data belonging to two students that violated the normality were excluded from analysis. The number of students included in the analysis was 82 .

One-way analysis of variance (ANOVA) was conducted to make between-groups comparisons based on the pretest, posttest and retention test results. The data showed that the assumptions of ANOVA were met. Post hoc tests were then used to identify between which groups there were statistically significant differences as a result of ANOVA. To reveal the effect size of the significant differences between the groups, Cohen's $d$ value was calculated. The significance level was taken as .05 in the study. In the statistical analysis, SPSS 21 (Statistical Package for Social Sciences 21) was used.

\section{Internal Validity}

According to Fraenkel, Wallen \& Hyun [23], "internal validity means that observed differences on the dependent variables are directly related to the independent variable and not due to some other unintended variable". In this regard, the possible threats that can come out with respect to the design of the study, which are the characteristics of subjects, mortality, attitudes of subjects, testing effect, history effect, implementation effect, implementer effect and maturation, were at the lowest level in this study. This is because the students who participated in the study were selected from the same socioeconomic level and achievement level, there were no loss of subjects throughout the process, and the students were exposed to activities towards the same outcomes on the same day. Besides, each group was included in the process with its own elementary school teacher. Experimental group teachers had no professional experience on the method they used that could provide an advantage during the implementation. On the other hand, the use of instruments as pretest, posttest and retention test in the study can be seen as a threat. The reason is that the change in the students' scores in the second and even the third administration of the test can be due to their having taken the test before. However, the fact that the control group answered the same test in the same time span reduces this threat. 


\section{Results}

\section{Findings of the Achievement Test}

The mean scores and standard deviations for the achievement pretest, posttest and retention tests are presented in Table 8 .

Table 8. Descriptive statistics of the achievement pretest, posttest, and retention test scores

\begin{tabular}{|c|c|c|c|c|c|c|c|}
\hline & $\begin{array}{c}\text { Number of } \\
\text { subjects }\end{array}$ & \multicolumn{2}{|c|}{ Pretest } & \multicolumn{2}{|c|}{ Posttest } & \multicolumn{2}{c|}{ Retention Test } \\
\hline Groups & $\mathrm{n}$ & $\bar{X}$ & $\mathrm{sd}$ & $\bar{X}$ & $\mathrm{sd}$ & $\bar{X}$ & $\mathrm{sd}$ \\
\hline Control & 18 & 8,33 & 2,16 & 10,44 & 1,54 & 10,33 & 1,08 \\
\hline Experiment 1 & 22 & 8,05 & 2,95 & 11,14 & 1,81 & 12,63 & 1,78 \\
\hline Experiment 2 & 21 & 8,29 & 3,43 & 12,29 & 1,82 & 12,76 & 1,54 \\
\hline Experiment 3 & 21 & 7,38 & 2,78 & 12,14 & 2,03 & 12,28 & 1,73 \\
\hline
\end{tabular}

*Maximum score is 15 points. $\bar{X}$ : Arithmetical mean; sd: Standard deviation

\section{Findings of the Achievement Pretest}

One-way analysis of variance for independent samples was conducted to test whether there was a significant difference between the means of the groups. The results of this analysis are presented in Table 9

Table 9. ANOVA results of the achievement pretest

\begin{tabular}{|c|c|c|c|c|c|}
\hline Source of Variance & Sum of Squares & sd & Mean of Squares & F & p \\
\hline Between-groups & 11,807 & 3 & 3,936 & 0,469 & .705 \\
\hline Within-groups & 654,193 & 78 & 8,387 & & \\
\hline Total & 666,000 & 81 & & & \\
\hline
\end{tabular}

As can be seen in Table 9, there was no statistically significant difference between the groups based on the achievement pretest, $\mathrm{F}(3,78)=0.469, \mathrm{p}>.05$. Based on this result, it can be stated that all the groups that participated in the study were equal in terms of their prior knowledge related to the unit "Let's Learn about Force".

\section{Findings of the Achievement Posttest}

One-way analysis of variance for independent samples was conducted to test whether there was a significant difference between the means of the groups after instruction. The results of this analysis are presented in Table 10.

Table 10. ANOVA results of the achievement posttest

\begin{tabular}{|c|c|c|c|c|c|c|c|}
\hline Source of Variance & Sum of Squares & sd & Mean of Squares & F & $\mathrm{p}$ & Partial $\eta 2$ & Force \\
\hline Between-groups & 44,498 & 3 & 14,833 & 4,486 & .006 & .147 & .87 \\
\hline Within-groups & 257,892 & 78 & 3,306 & & & & \\
\hline Total & 302,390 & 81 & & & & \\
\hline
\end{tabular}

The results of the analysis showed that there was a significant difference between science achievement of the groups, $\mathrm{F}(3$, $78)=4.486, p<.05, \eta^{2}=.147$. The partial eta-squared value indicated that the effect size was large (Green, Salkind \& Akey, 2000 ). In addition, the statistical power value was .87 , which is above the acceptable value (.80) in the literature. According to the results of the Bonferroni test conducted to determine between which groups the observed differences occurred (see Table 11), the science achievement of the experimental groups in which science concepts were taught during and at the end of the activities were significantly higher than that of the control group.

Table 11. Bonferroni test results of the achievement posttest

\begin{tabular}{|c|c|c|c|c|c|}
\hline & (I)Group & $(J)$ Group & Mean difference (I-J) & Standard error & $\mathrm{p}$ \\
\hline \multirow{3}{*}{ Bonferroni } & \multirow{3}{*}{ Control } & Experiment 1 &,- 69192 &, 57790 & 1,000 \\
\cline { 3 - 6 } & & Experiment 2 & $-1,84127^{*}$ &, 58406 & .014 \\
\cline { 3 - 6 } & & Experiment 3 & $-1,69841^{*}$ &, 58406 & .028 \\
\hline
\end{tabular}

* The mean is significant at the level of .05 . 
Cohen's d values were calculated to interpret the effect size of the means that were found to be significant. Accordingly, it was found as $\mathrm{d}=0.95$ for the control and Experiment 2 groups, while it was $\mathrm{d}=0.87$ for the control and Experiment 3 groups. Based on the criteria for interpreting the Cohen's effect size, the observed effect sizes were large in favour of the experimental groups.

\section{Findings of the Achievement Retention Test}

One-way analysis of variance for independent samples was conducted to test whether there was a significant difference between the means of the groups in the achievement retention test administered six months after the instruction. The results of this analysis are presented in Table 12.

Table 12. ANOVA results of the achievement retention test

\begin{tabular}{|c|c|c|c|c|c|c|c|}
\hline Source of Variance & Sum of Squares & $\mathrm{sd}$ & Mean of Squares & $\mathrm{F}$ & $\mathrm{p}$ & ${\text { Partial } \eta^{2}}^{\text {Force }}$ \\
\hline Between-groups & 72.375 & 3 & 24.125 & 9,641 & .000 & .270 & .99 \\
\hline Within-groups & 195.186 & 78 & 2.502 & & & & \\
\hline Total & 267.561 & 81 & & & & & \\
\hline
\end{tabular}

As is seen in Table 12, there was a significant difference between the groups in terms of their retention levels six months after the unit "Let's Learn About Force" was covered, $F(3,78)=9.641, \mathrm{p}<.05, \mathrm{\eta}^{2}=.270$. Besides, the effect size was large, and the statistical power of the test was considerably high. According to the results of the Bonferroni test conducted to determine between which groups these differences occurred (see Table 13), the achievement retention scores of the experimental groups in which science concepts were taught at the beginning of, during and at the end of the activities were significantly higher than those of the control group.

Table 13. Bonferroni test results of the achievement retention test

\begin{tabular}{|c|c|c|c|c|c|}
\hline & (I)Group & (J) Group & Mean difference (I-J) & Standard error & $\mathrm{p}$ \\
\hline \multirow{3}{*}{ Bonferroni } & \multirow{3}{*}{ Control } & Experiment 1 & $-2,30303 *$ &, 50276 & .000 \\
\hline & & Experiment 2 & $-2,42857 *$ &, 50812 & .000 \\
\hline & & Experiment 3 & $-1,195238 *$ & ,50812 & .001 \\
\hline
\end{tabular}

* The mean is significant at the level of .05.

Cohen's $d$ values were calculated to interpret how far the group means dispersed from each other, and it was found as $\mathrm{d}=1.27$ for the control and Experiment 1 groups, $\mathrm{d}=1.33$ for the control and Experiment 2 groups, and $\mathrm{d}=1.07$ for the control and Experiment 3 groups. Based on the criteria for interpreting the Cohen's effect size, the effect sizes were large in favour of the experimental groups.

\section{Findings of the EPA Test}

The means and standard deviations for the EPA test administered at the end of the experimental procedure and six months after are presented in Table 14.

Table 14. Descriptive statistics of the EPA test

\begin{tabular}{|c|c|c|c|c|c|}
\hline & Number of subjects & \multicolumn{2}{|c|}{ Post-Instruction Test } & \multicolumn{2}{|c|}{ Retention Test } \\
\hline Groups & $\mathrm{n}$ & $\bar{X}$ & $\mathrm{sd}$ & 11.55 & $\mathrm{~s}$ \\
\hline Control & 18 & 11.33 & 1.33 & 12.59 & 1.08 \\
\hline Experiment 1 & 22 & 10.95 & 1.62 & 13.19 & 1.78 \\
\hline Experiment 2 & 21 & 11.81 & 1.54 & 12.07 & 1.54 \\
\hline Experiment 3 & 21 & 11.86 & 1.31 & & 1.73 \\
\hline
\end{tabular}

\section{Findings of the EPA post-instruction test}

One-way analysis of variance for independent samples was conducted to test whether there was a significant difference between the groups. The results of this analysis are presented in Table 15 
Table 15. ANOVA results of the EPA post-instruction test

\begin{tabular}{|c|c|c|c|c|c|}
\hline Source of Variance & Sum of Squares & sd & Mean of Squares & F & p \\
\hline Between-groups & 11.724 & 3 & 3.908 & & .149 \\
\hline Within-groups & 166.764 & 78 & 2.138 & & \\
\hline Total & 178.488 & 81 & & \\
\hline
\end{tabular}

As is seen in Table 15, there was no statistically significant difference between the experimental groups that received science instruction integrated with the GPA course, and the control group, $\mathrm{F}(3,78)=1.828, \mathrm{p}>.05$.

\section{Findings of the EPA Retention Test}

One-way analysis of variance for independent samples was conducted to test whether there was a significant difference between the groups. The results of this analysis are presented in Table 16.

Table 16. ANOVA results of the EPA Retention Test

\begin{tabular}{|c|c|c|c|c|c|c|c|}
\hline Source of Variance & Sum of Squares & $\mathrm{sd}$ & Mean of Squares & $\mathrm{F}$ & $\mathrm{p}$ & Partial $\eta^{2}$ & Force \\
\hline Between-groups & 26.375 & 3 & 8.812 & 4,093 & .009 & .136 & .83 \\
\hline Within-groups & 167.953 & 78 & 2.153 & & & & \\
\hline Total & 194.390 & 81 & & & & & \\
\hline
\end{tabular}

As is seen in Table 16, there was a significant difference between the groups in terms of their retention levels, $\mathrm{F}$ $(3,78)=4.093, p<.05, \eta^{2}=.136$. The effect size was close to being large, and the statistical power was above 0,80 . According to the results of the Bonferroni test conducted to determine between which groups this difference occurred (see Table 17), the retention scores of the experimental groups in which science concepts were taught during the activities were significantly higher than those of the control group.

Table 17. Bonferroni test results of the EPA retention test

\begin{tabular}{|c|c|c|c|c|c|}
\hline & (I)Group & (J)Group & Mean difference (I-J) & Standard error & $\mathrm{p}$ \\
\hline \multirow{3}{*}{ Bonferroni } & \multirow{3}{*}{ Control } & Experiment 1 & -1.03535 & ,46637 & .176 \\
\hline & & Experiment 2 & $-1,63492 *$ & ,47134 & .005 \\
\hline & & Experiment 3 &,- 82540 & ,47134 & .503 \\
\hline
\end{tabular}

* The mean is significant at the level of .05 .

Cohen's d value was calculated to interpret the effect size of the difference between the group means, and it was found as $d=1.05$ for the control and Experiment 2 groups. Based on the criteria for interpreting the Cohen's effect size, it can be stated that there was a large difference between the means in favour of the group Experiment 2.

\section{Discussion, Results and Suggestions}

This study investigated the effect of science teaching conducted with an interdisciplinary teaching approach through the GPA course on students' academic achievement in science and retention of science knowledge. The analyses showed that it positively affected the students' science achievement. This result is consistent with those reported in Hatch and Smith [8], Placek and Patton [9], Werner [10], Yi [11], Buchanan et al. [14], Hastie [15], Provost [16], and Seeds, Pollom and Burton [17]. While these studies presented science concepts to students through physical education skills, the current study presented these skills to students through gamification, which is a difference on behalf of this study. An example is the game "Turkish
Baseball" that can develop students' skill of hitting the ball with a racket. Similarly, the game "Rabbit Race" is an activity towards developing students' skill of jumping. One way of implementing these practices effectively can be doing physical activities through gamification.

Another issue examined in the study was the timing of introduction of science concepts associated with the GPAs. The experimental group in which the science concepts were taught during the activities was more successful in science achievement than the other experimental groups. According to Piaget [25], third grade students (9 years old) participated in the study are in the stage of concrete operations in which the child is not capable of dealing yet with propositions or abstract conceptions. From this point of view, it can be argued that students in the experimental group two learned science concepts simultaneously when they appeared in the GPAs would be more successful than the other experimental groups in which students were introduced science concepts before or after the GPAs that might probably makes science concepts abstract for the students due to the time interval between presentation of concepts and their appearance in the GPAs.

In case the achievement test developed by the researchers 
had a bias for the experimental groups, the EPA test was also administered in accordance with the instruction followed in the control group. The finding that the students in the experimental groups did not perform lower than those in the control group in the EPA test administered after the implementation can be interpreted as the success of the science instruction based on the GPA course. At the same time, the GPA-based science instruction also contributed to the students' retention levels as shown in the achievement and EPA retention tests.

In order to balance the duration of instruction in the control and the experimental groups, the experimental groups received the GPA-based instruction only in the science course. It can be argued that if teachers normally use other teaching approaches in science lessons, they can achieve more effective science instruction when they use the GPA course with the approach adopted in this study.

Based on the results of the study, it can be suggested for elementary school teachers who aim to teach science in an experiential, entertaining and active environment to use the GPA course in accordance with the interdisciplinary teaching approach. Guide booklets including lesson plans and information for teachers on how to use game materials, game rules, and games should be prepared in order to easily put GPA-based science instruction into practice. In this respect, there is a need to develop an inventory showing the overlap between the concepts in the games and science. Alternative materials should also be available in the case of a possible setback that can be encountered in GPA-based science instruction. For example, in this study, a Frisbee was stuck on a tree in the school garden during the game "Flying Saucer". At that moment, a spare Frisbee was used to be able to continue to the activity. Students can encounter minor accidents (e.g. crashing into each other, falling down while running) during the play in the school garden. In this regard, practitioners should be careful and take the necessary measures.

The model implemented in this study to integrate the unit "Let's Learn about Force" of the science course with the GPA course can also be used to integrate other units of the science course in further studies and its effectiveness can be tested. In addition, conducting studies towards the usability of the science and GPA courses with integration to other disciplines can provide opportunities to present both the science and the GPA course more effectively to students.

\section{REFERENCES}

[1] Pica, R. (2014). Early elementary children moving and learning: A physical education curriculum. Redleaf Press.

[2] Pica, R. (2000). Moving and learning series: Toddlers. Delmar Publishers.

[3] Cone, T.P., Werner, P., Cone, S.L., \& Woods, A.M. (1998).
Interdisciplinary Teaching through Physical Education. Champaign, Il: Human Kinetics Publishing.

[4] Gagen, L. \& Getchell, N. (2008). Applying Newton's apple to elementary physical education, Journal of Physical Education, Recreation and Dance, 79(8), 43-51

[5] Konukman, F. \& Marx, A. C. (2009). An Interdisciplinary Approach to Physical Education and Sport: An In-class Activity. Journal of Physical Education, Recreation \& Dance, 80(4), 12-13.

[6] Beane, J. (1991). The middle school: The natural home of integrated curriculum. Educational Leadership. 49(2), 9-13.

[7] Yıldırım, A. (1996). Disiplinler arası öğretim kavramı ve programlar açısından doğurduğu sonuçlar. Hacettepe Üniversitesi Eğitim Fakültesi Dergisi, 12, 89-94

[8] Hatch, G. M. \& Smith, D. R. (2004). Integrating physical education, math and physics. Journal of Physical Education, Recreation ve Dance, 75(1), 42-50.

[9] Placek, J.H. \& Patton, K. G. (2002). Integrated physical education curriculum: students' conceptions of newton's law. Research Qarterly Exercise and Sports, 73, 1-116, Abstract retrieved July 2, 2014, from http://dx.doi.org/10.1080/02701367.2002.10609056

[10] Werner, P.H. (1971). Effects of integration of physical education with selected science concepts upon science knowledge and selected physical performance skills of boys and girls at fourth, fifth and sixth grade levels. Unpublished master dissertation. Indiana Üniversitesi, Bloomington, IN.

[11] Yi, X. (2004). Implementation and effectiveness of the integrated curriculum in physical education class. Research Qarterly Exercise and Sports, 73, 1-123, Abstract retrieved July 2, 2014, from http://dx.doi.org/10.1080/02701367.2004.10609185

[12] Pehlivan, H. (2012). Oyun ve öğrenme. Ankara: Anı Yayıncilik

[13] Erdoğan, S. (2011). Okul öncesi fen öğretiminde başlıca kuram, yaklaşım ve öğretim yöntemleri. A. Özdaş, (Edt.) Okul öncesinde fen eğitimi içinde. (ss. 159-175). Eskişehir: Anadolu Üniversitesi Yayını

[14] Buchanan, A.M., Martin, E., Childress, R., Howard, C., Williams, L., Bedsole, B. \& Ferry, M. (2002). Integrating elementary physical education and science: A cooperative problem-solving approach. Journal of Physical Education, Recreation and Dance, 73(2), 31-36, DOI: 10.1080/07303084.2002.10607751

[15] Hastie, P. A. (2013). The Biome Project: Developing a legitimate parallel curriculum for physical education and life sciences. Education 3-13: International Journal of Primary, Elementary and Early Years Education, 41(5), 462-476, DOI: 10.1080/03004279.2011.607173

[16] Provost, C. L. (2012). Effects of varying levels of physical activity on middle school students' science knowledge retention. Unpublished master dissertation, Northern Michigan University, Michigan.

[17] Seeds, A., Pollom, G. \& Burton, B. (2015). Physical education meets physical science. Science and Children. (February), (52),6, 39-44 
[18] Christensen, L. B., Johnson, R. B., \& Turner, L. A. (2015). Araştırma yöntemleri desen ve analiz. Aypay A. (Çeviri Edt.). Ankara: Anı Yayıncılık

[19] Drake, S.M. (1993). Planning integrated curriculum: the call to adventure. Alexandria, VA: Association for Supervision and Currciulum Development

[20] Fogarty, R. (1991). Ten ways to integrated curriculum. Educational Leadership. 47(2), 61-65

[21] Jacobs, H.H., (1989), Design options for an integrated curriculum. In H.H. Jacobs (Edt.), Interdisciplinary curriculum: Design and implementation. Alexandria, Va: Association For Supervision And Curriculum Development.
[22] Placek, H.J. \& O'sullivan, M. (1997). The many faces of integrated physical education. Journal of Physical Education, Recreation and Dance, 68 (1), 20-24, DOI: $10.1080 / 07303084.1997 .10604872$

[23] Fraenkel, J. R., Wallen, N. E. \& Hyun, H. H. (2012). How to design and evaluate research in education (8th ed.). New York: McGraw-Hill, Inc.

[24] Green, S. B., Salkind, N. J. \& Akey, T. M. (2000). Using SPSS for Windows analyzing and understanding data (2nd ed.). Upper Saddle River, New Jersey.

[25] Piaget, J. (1962). The stages of the intellectual development of the child. Bulletin of the Menninger Clinic, 26, 120-128. 